\author{
Maria Sierpińska \\ Wyższa Szkoła Finansów i Zarządzania w Warszawie \\ e-mail: msierpinska@o2.pl
}

\title{
Beata Kulisa
}

Uniwersytet Ekonomiczny w Krakowie

e-mail: bkulisa@interia.pl

\section{KOSZTY FINANSOWANIA DŁUŻNEGO W ŚWIETLE NOWYCH ROZWIĄZAŃ PODATKOWYCH}

\section{COSTS OF DEBT FINANCING IN THE LIGHT OF NEW TAX SOLUTIONS}

DOI: $10.15611 /$ pn.2018.514.37

JEL Classification: O16.

Streszczenie: W artykule zaprezentowano problem limitowania kosztów finansowania dłużnego. Dotychczas ograniczenia dotyczące zaliczania odsetek do kosztów podatkowych odnosiły się tylko do pożyczek wewnątrzkorporacyjnych. 1 stycznia 2018 r. wprowadzone zostały nowe zasady: podstawę opodatkowania pomniejszają koszty finansowania długiem, nieprzekraczające 3 mln zł, powiększone o 30\% EBITDA. W nowych rozwiązaniach podatkowych wprowadzono kategorie rynkowej zdolności kredytowej, która oceniana będzie przez organy podatkowe. Pominięto grupy kapitałowe, w których spółki wewnętrzne mają wyższą zdolność kredytową niż pojedyncze podmioty gospodarcze. Problemy dotyczące rynkowej oceny zdolności kredytowej będą miały również małe podmioty i spółki rozpoczynające działalność gospodarczą. Często nie mają one zdolności kredytowej, gdyż nie posiadają majątku do zabezpieczenia długów. Obce źródła finansowania przedsiębiorstw w Polsce są droższe niż w krajach wysoko rozwiniętych. Może to ograniczać rozwój przedsiębiorstw i pogarszać ich konkurencyjność.

Słowa kluczowe: odsetki, koszty finansowania dłużnego, rynkowa zdolność finansowa.

Summary: The article presents a problem of limiting costs of debt financing. So far the limitations concerning the inclusion of interest on tax to tax costs have related only to intracorporate loans. Since 1 January 2018 new regulations have been introduced in this respect. The taxable amount is decreased by costs of debt financing not exceeding PLN 3 million increased by $30 \%$ EBITDA. In new tax solutions, a market credit worthiness category has been introduced, which will be assessed by tax authorities. Capital groups, in which internal companies have greater creditworthiness than individual business entities, have been disregarded. Also small entities and companies starting business activity will have problems connected with the market assessment of creditworthiness. Very often they do not have 
credit worthiness since they do not have assets to secure debts. Outside sources of financing enterprises in Poland are more expensive than in highly developed countries. This may limit the development of enterprises and worsen their competitiveness.

Keywords: interests, costs of debt financing, market financial creditworthiness.

\section{Wstęp}

Do 2018 r. koszty zewnętrznego finansowania dłużnego w Polsce nie były w zasadzie limitowane. Jedynie ustawa o tzw. cienkiej kapitalizacji ograniczała zaliczenie do kosztów podatkowych odsetek od pożyczek wewnątrzgrupowych. Bez ograniczeń do kosztów uzyskania przychodów pomniejszających podstawę opodatkowania wliczane były odsetki, prowizje, marże dyskonta i inne koszty korzystania $\mathrm{z}$ zewnętrznych kapitałów obcych. Zróżnicowanie przepisów podatkowych, zwłaszcza stawek w poszczególnych krajach, spowodowało, że wiele firm korzystało z rozwiązań optymalizacji podatkowej. Odsetki od długów wykorzystywane były jako jedna z metod erozji podstawy opodatkowania. Dodatkowo próba zmniejszenia ryzyka kryzysu finansowego wynikającego z nadmiernego zadłużenia skłoniła wiele krajów do wdrożenia reguł prawnych ograniczających możliwość zaliczenia odsetek od długów do kosztów pomniejszających podstawę opodatkowania. Wzorem innych krajów również w Polsce od 1 stycznia 2018 r. obowiązują nowe rozwiązania wprowadzające limit kosztów finansowania dłużnego.

Celem artykułu jest ocena zmian w rozwiązaniach prawnych dotyczących zaliczania kosztów finansowania dłużnego do kosztów pomniejszających podstawę opodatkowania. Oparto ją na analizie literatury przedmiotu nt. dotychczasowych rozwiązań w badanym obszarze, wprowadzonych nowych rozwiązań prawnych oraz danych zamieszczonych na stronach internetowych.

\section{Koszty finansowania dłużnego a podstawa opodatkowania}

We współczesnych systemach podatkowych odsetki od długów są uznawane za koszty działalności, które zmniejszają podstawę opodatkowania. Jednak zdecydowana większość państw stosuje ograniczenia w odliczaniu odsetek, chociaż szczegółowe regulacje są bardzo zróżnicowane. Różnią się one między sobą w odniesieniu do dwóch kwestii. Pierwszą jest pochodzenie długu - w części jurysdykcji ograniczenia dotyczą wyłącznie odsetek od zadłużenia pozyskanego od podmiotów powiązanych (dług wewnętrzny), a w części - od wszystkich podmiotów. Druga z nich to sposób ustalania limitu jako wskaźnika określającego relację między kapitałem obcym i kapitałem własnym lub jako określonego procentu zysku. Na ogół o regulacjach dotyczących niedostatecznej kapitalizacji mówi się w sytuacji, gdy ograniczenie w odliczaniu odsetek ma miejsce po przekroczeniu określonej warto- 
ści zadłużenia (całkowitego lub wewnętrznego). Istnieją też rozwiązania, które uzależniają możliwość zaliczania odsetek od długu od rentowności przedsiębiorstwa [Leszczyłowska 2017, s. 78]. Do końca 2017 r. Polska należała do krajów, w których regulacje prawne ograniczające zaliczenie odsetek do kosztów podatkowych odnosiły się tylko do zadłużenia wewnętrznego. Regulowała je ustawa o tzw. cienkiej kapitalizacji. Od stycznia 2018 r. limitowaniu podlegają szeroko pojęte odsetki, tzw. koszty finansowania dłużnego od całego zaciągniętego długu, bez względu na jego pochodzenie.

Zmiany dotyczące zaliczania odsetek od pożyczek i innych obcych źródeł finansowania do kosztów podatkowych wprowadziła ustawa o zmianie ustawy o podatku dochodowym od osób fizycznych, ustawy o podatku dochodowym od osób prawnych oraz ustawy o zryczałtowanym podatku dochodowym od niektórych przychodów osiąganych przez osoby fizyczne [Ustawa z 27 października 2017]. W ustawie wykreślone zostały w całości przepisy regulujące dotychczas niedostateczną kapitalizację (art. 16, ust. 1, pkt 60 i 61 ustawy o CIT). Wprowadzone w Polsce rozwiązania oparte są na przepisach wspólnotowych, tj. dyrektywie Rady (UE) 2016/1164 z 12 lipca 2016 r. ustanawiającej przepisy mające na celu przeciwdziałanie praktykom unikania opodatkowania, które mają bezpośredni wpływ na funkcjonowanie rynku wewnętrznego.

Dotychczasowe rozwiązania w Polsce umożliwiały przedsiębiorstwom międzynarodowym wkalkulowanie w koszty nadmiernych odsetek i zmniejszenie takim sposobem zobowiązań podatkowych. Ograniczenia dotyczyły tylko podmiotów powiązanych i nie zabezpieczały przed zmniejszaniem opodatkowania. W celu ominięcia przepisów dotyczących cienkiej kapitalizacji przedsiębiorstwa międzynarodowe wykorzystywały pożyczki fasadowe, równoległe, pożyczki typu back-to-back, od których odsetki mogły być bez ograniczeń zaliczone do kosztów podatkowych. Ustawa wprowadziła trzy fundamentalne zmiany, obejmujące (niedostateczna kapitalizacja):

1) przyjęcie całkowicie nowej metody kalkulacji limitu kosztów odsetkowych;

2) objęcie tymi przepisami szerokiego zakresu zdarzeń (w tym pożyczek udzielanych przez podmioty niepowiązane), jak również szerokie zdefiniowanie kosztów finansowania dłużnego;

3) wprowadzenie możliwości „przenoszenia” nieodliczonych w danym roku odsetek na następne lata podatkowe.

Istota nowego limitu odsetkowego została wyjaśniona w art. 15c, ust. 1 ustawy o CIT. Według tego rozwiązania podatnicy będą mogli zaliczyć do kosztów podatkowych w danym roku koszty finansowania nie wyższe niż $3 \mathrm{mln}$ zł powiększone o 30\% EBITDA (earnings before interest, taxes, depreciation and amortization), czyli wynik finansowy przed odjęciem odsetek, amortyzacji i opodatkowaniem. EBITDA, zgodnie przepisami podatkowymi, ustalana będzie jako różnica między sumą przychodów z wszystkich źródeł (bez przychodów finansowych o charakterze odsetkowym) a sumą kosztów uzyskania przychodów pomniejszonych o odpisy 
amortyzacyjne oraz koszty finansowania dłużnego nieuwzględnione w wartości początkowej środka trwałego lub wartości niematerialnej i prawnej. Ustalając limit odsetkowy, nie uwzględnia się też m.in. dochodów niepodlegających opodatkowaniu albo wolnych od podatku, jak również strat przedsiębiorców przekształcanych, łączonych, przejmowanych lub dzielonych. Ponadto przy kalkulacji limitu nie bierze się pod uwagę pomniejszeń wynikających z zastosowania art. 15c, ust. 1 oraz art. 15 e, ust. 1 tej ustawy, czyli wprowadzonego wyłączenia z kosztów części wartości usług niematerialnych nabytych od podmiotów powiązanych ${ }^{1}$.

Nadwyżkę kosztów finansowania dłużnego ponad 30\% tak ustalonego wyniku finansowego przedsiębiorstwa będą musiały wyłączyć z kosztów uzyskania przychodów w danym roku podatkowym. Koszty te będą mogły być zaliczone do kosztów podatkowych w następnych 5 latach. Zaliczenie nadwyżki do kosztów podatkowych w kolejnych latach musi nastąpić zgodnie z zasadami określonymi w art. 15c ustawy o CIT oraz w ramach obowiązujących w danym roku limitów wynikających $\mathrm{z}$ tych przepisów. Zaprezentowane powyżej ograniczenia dotyczące ujęcia w kosztach podatkowych kosztów finansowania dłużnego nie będą miały zastosowania, jeśli koszty te nie przekroczą $3 \mathrm{mln}$ zł.

W celu poprawnego ustalenia sumy kosztów finansowych, które mogą być zaliczone do kosztów podatkowych w danym roku, w ustawie sprecyzowane zostały pojęcia „kosztów finansowania dłużnego” oraz „przychodów o charakterze odsetkowym".

Przez „koszty finansowania dłużnego” rozumiane są wszelkiego rodzaju koszty związane z pozyskaniem i korzystaniem w określonym czasie ze środków pochodzących od innych podmiotów. Nie ma więc znaczenia, od kogo środki te zostały pozyskane: czy od podmiotu powiązanego kapitałowo z podatnikiem, czy od niepowiązanego, np. od banku. Koszty finansowania dłużnego obejmą zatem odsetki (w tym skapitalizowane lub ujęte $w$ wartości początkowej środka trwałego lub wartości niematerialnej i prawnej), opłaty, prowizje, premie, część odsetkową raty leasingowej, kary i opłaty za opóźnienie w zapłacie zobowiązań oraz koszty zabezpieczenia zobowiązań (w tym koszty pochodnych instrumentów finansowych, niezależnie od tego na rzecz kogo zostały one poniesione). Do kosztów uznanych za koszty podatkowe należą również prowizje i inne opłaty dla banku za przedterminową spłatę kredytów.

1 Zgodnie z treścią nowego art. 15e ustawy o CIT podatnicy są zobowiązani wyłączyć z kosztów uzyskania przychodów wydatki na: usługi doradcze, badania rynku, usługi reklamowe, zarządzania i kontroli, przetwarzania danych, ubezpieczeń, gwarancji i poręczeń oraz świadczeń o podobnym charakterze, a także wszelkiego rodzaju opłaty i należności za korzystanie lub prawo do korzystania z praw autorskich lub pokrewnych praw majątkowych, licencji, praw własności przemysłowej, jak również przeniesienie ryzyka niewypłacalności dłużnika z tytułu pożyczek, innych niż udzielonych przez banki i spółdzielcze kasy oszczędnościowo-kredytowe, w tym w ramach zobowiązań wynikających z pochodnych instrumentów finansowych oraz świadczeń o podobnym charakterze (np. ryzyko pozostające po faktoringu niepełnym). Nielimitowane koszty na wymienione wyżej cele wynoszą $3 \mathrm{mln}$ zł. Jeżeli wydatki powyżej $3 \mathrm{mln}$ zł w danym roku podatkowym przekraczają 5\% EBIDTA podatnika, to w tej części nie mogą być uznane za koszty podatkowe. 
Niekiedy firmy dokonują restrukturyzacji kredytów poprzez zaciągnięcie nowego kredytu na korzystniejszych warunkach na spłatę kredytów wcześniejszych. Urzędy skarbowe zazwyczaj nie wyrażały zgody na zaliczenie w ciężar kosztów podatkowych kosztów ponoszonych w związku z restrukturyzacją kredytów, traktując je jako koszty nieuzasadnione ekonomicznie. Zgodnie z nowymi rozwiązaniami prawnymi koszty te są kosztami uzyskania przychodów. Przychody o charakterze odsetkowym stanowią natomiast przychody z tytułu odsetek oraz inne przychody równoważne ekonomicznie odsetkom sprecyzowane w kosztach finansowania dłużnego. Zaprezentowanych powyżej ograniczeń dotyczących zaliczenia kosztów finansowania dłużnego do kosztów podatkowych nie będą musiały stosować przedsiębiorstwa finansowe, czyli banki krajowe, instytucje kredytowe, SKOK-i, zakłady ubezpieczeń, a także fundusze inwestycyjne otwarte oraz alternatywne fundusze inwestycyjne utworzone na podstawie ustawy o funduszach inwestycyjnych. Za przedsiębiorstwo finansowe nie są uznawane instytucje pożyczkowe.

Ponadto, przy wyliczaniu nadwyżki kosztów finansowania dłużnego ponad limit określony $\mathrm{w}$ ustawie, nie są brane pod uwagę koszty finansowania dłużnego wynikające z kredytów (pożyczek) wykorzystywanych do sfinansowania długoterminowego projektu z zakresu infrastruktury publicznej ${ }^{2}$, w przypadku którego spełnione są łącznie następujące warunki (niedostateczna kapitalizacja):

- wykonawca projektu podlega opodatkowaniu w państwie członkowskim Unii Europejskiej;

- aktywa, których projekt dotyczy, znajdują się w całości w państwie członkowskim Unii Europejskiej;

- koszty finansowania zewnętrznego są wykazywane dla celów podatkowych w całości w państwie członkowskim Unii Europejskiej;

- dochody są osiągane w całości w państwie członkowskim Unii Europejskiej.

Zmieniona ustawa o CIT wprowadza rozwiązania dające urzędom skarbowym możliwość kontroli tzw. rynkowej zdolności kredytowej podatnika. Urząd może bowiem uznać, że dług uzyskany od podmiotu powiązanego jest za wysoki, a firma nie uzyskałaby takiej wartości długu, gdyby finansowanie to zostało jej udzielone przez podmioty niepowiązane. Organ podatkowy może wówczas wyłączyć z kosztów podatkowych odsetki od finansowania przekraczającego rynkową zdolność kredytową podatnika. Rozwiązania podatkowe pomijają niestety powiązania kapitałowe między podmiotami. Przy ocenie rynkowej zdolności kredytowej urzędy skarbowe nie uwzględnią zabezpieczeń udzielonych przez podmioty powiązane kapitałowo ani zdolności kredytowej wynikającej z istnienia tych powiązań. Oznacza to, że gwarancje czy poręczenia przyznane przez spółkę grupy kapitałowej nie uchronią

2 Długoterminowy projekt z zakresu infrastruktury publicznej to projekt służący dostarczeniu, modernizacji, eksploatacji lub utrzymaniu znaczącego składnika aktywów, będący w ogólnym interesie publicznym. Dochodu wynikającego z długoterminowego projektu z zakresu infrastruktury publicznej nie będzie się uwzględniać przy obliczaniu przychodów i kosztów, o których mowa w art. 15c ust. 1 ustawy o CIT. 
podatnika przed ryzykiem zakwestionowania rozliczenia odsetek w koszty. Może to stanowić problem dla nowo tworzonych spółek w grupie kapitałowej, które nie mają ani historii kredytowej, ani rynkowej zdolności kredytowej, a kredyt uzyskały w wyniku poręczenia spółki-matki lub innej spółki z grupy. Nowe rozwiązania podatkowe są więc niekorzystne dla spółek powiązanych, czyli w obszarze, gdzie normalne mechanizmy rynkowe mogą nie zadziałać.

Rozwiązania zawarte w ustawie o CIT są niekorzystne również dla nowych podmiotów, niepowiązanych kapitałowo, np. spółek celowych, które na początku działalności mogą nie mieć wymaganej zdolności kredytowej. W przepisach nie ma żadnych ograniczeń kwotowych, co oznacza, że organy podatkowe mogą kontrolować poziom zadłużenia bardzo małych podmiotów, które na początku swojej działalności korzystają z pożyczek i kredytów zabezpieczonych prywatnym majątkiem właścicieli spółek. Problemy mogą mieć też firmy duże ze względu na subiektywność ocen urzędników skarbowych, niemających dostatecznej wiedzy finansowej. Jeżeli uznają oni, że spółka pożyczyła więcej, niż pozwala jej na to rynkowa zdolność kredytowa, zakwestionują rozliczenie odsetek w ciężar kosztów podatkowych. Firmy będą zmuszone sięgać po dodatkowe instrumenty zabezpieczające ryzyko kredytowania, co zwiększy koszty finansowe i ograniczy zdolność do zaciągania nowych długów. Może to wpłynąć negatywnie na tempo rozwoju niektórych firm.

\section{Koszty korzystania z kredytów bankowych}

Podstawowym kosztem korzystania z kredytu jest oprocentowanie składające się z kosztu pieniądza, wynikającego bezpośrednio z obiektywnych warunków panujących na rynku, i marży banku. Rynek depozytów i kredytów udzielanych sobie przez instytucje finansowe pozwala na wyznaczanie i publikowanie obowiązujących w danym czasie stóp procentowych. Stopy te zazwyczaj stanowią bazę naliczania wartości zmiennych odsetek w odpowiednich okresach odsetkowych (np. 1, 3, 6 miesięcy), co wpływa na wybór stopy referencyjnej i częstotliwości dokonywania płatności. W tabeli 1 pokazany został poziom stóp procentowych WIBOR, LIBOR i EURIBOR. W krajach wysoko rozwiniętych stopy procentowe są ujemne.

Tabela 1. Poziom stóp procentowych WIBOR, LIBOR I EURIBOR (stan na 6.03.2018)

\begin{tabular}{|l|c|c|c|}
\hline \multicolumn{1}{|c|}{ Okres } & WIBOR & LIBOR & EURIBOR \\
\hline $\mathrm{ON}$ & 1,55 & $-0,7812$ & - \\
\hline $1 \mathrm{M}$ & 1,65 & $-0,8124$ & $-0,3710$ \\
\hline $3 \mathrm{M}$ & 1,72 & $-0,7446$ & -03270 \\
\hline $6 \mathrm{M}$ & 1,81 & $-0,6634$ & -02710 \\
\hline $9 \mathrm{M}$ & 1,82 & - & $-0,2220$ \\
\hline $1 \mathrm{Y}$ & 1,85 & $-0,5314$ & $-0,1910$ \\
\hline
\end{tabular}

Źródło: [https://www.bankier.pl/kredyty-hipoteczne/stopyprocentowe/wibor/libor/euribor]. 
Wprowadzono je, po kryzysie finansowym z lat 2007-2009, w strefie euro i kilku innych krajach, m.in. w Szwajcarii, Szwecji, Danii i Japonii. Mechanizm ujemnych stóp procentowych zakłada, że banki centralne - biorąc od banków komercyjnych gotówkę - oddają ją pomniejszoną o ujemną stopę procentową. Miało to skłonić banki do zwiększenia akcji kredytowej. Podmioty gospodarcze pozyskaną bardzo tanio gotówkę przeznaczyłyby na inwestycje [Klepacki 2016, s. 7]. W Polsce WIBOR jest relatywnie wysoki na tle stawek w krajach wysoko rozwiniętych, co podnosi koszty korzystania z kredytów bankowych i może ograniczać rozwój podmiotów gospodarczych. Wysokie są też średnie marże od kredytów w porównaniu z krajami, z którymi na rynku unijnym muszą konkurować polskie podmioty gospodarcze (tab. 2).

Tabela 2. Średnie marże banków od kredytów w wybranych krajach (listopad 2017, w p.p.)

\begin{tabular}{|r|l|c|c|c|l|c|c|}
\hline Lp. & Kraje & $\begin{array}{c}\text { Marża } \\
\text { od } \\
\text { kredytów } \\
\text { dla firm }\end{array}$ & $\begin{array}{c}\text { Marża od } \\
\text { kredytów } \\
\text { na zakup } \\
\text { nieruchomości }\end{array}$ & Lp. & Kraje & $\begin{array}{c}\text { Marża od } \\
\text { kredytów } \\
\text { dla firm }\end{array}$ & $\begin{array}{c}\text { Marża } \\
\text { od kredytów } \\
\text { na zakup } \\
\text { nieruchomości }\end{array}$ \\
\hline 1 & Grecja & 3,56 & 2,27 & 15 & Słowacja & 1,77 & 1,38 \\
\hline 2 & Rumunia & 3,21 & 3,30 & 16 & Estonia & 1,72 & 1,79 \\
\hline 3 & Bułgaria & 3,19 & 3,63 & 17 & Belgia & 1,64 & 2,27 \\
\hline 4 & Malta & 2,71 & 1,99 & 18 & Dania & 1,54 & 2,68 \\
\hline 5 & Irlandia & 2,71 & 3,09 & 19 & Finlandia & 1,54 & 0,78 \\
\hline 6 & Łotwa & 2,60 & 2,15 & 20 & Litwa & 1,48 & 1,76 \\
\hline 7 & Portugalia & 2,36 & 1,32 & 21 & Węgry & 1,38 & 4,10 \\
\hline 8 & Cypr & 2,29 & 1,31 & 22 & Niemcy & 1,33 & 1,77 \\
\hline 9 & Słowenia & 2,26 & 2,17 & 23 & Francja & 1,30 & 1,45 \\
\hline 10 & Chorwacja & 2,22 & 2,70 & 24 & Holandia & 1,28 & 2,25 \\
\hline 11 & Polska & 2,20 & 3,06 & 25 & Luksemburg & 1,19 & 1,65 \\
\hline 12 & Hiszpania & 1,82 & 1,77 & 26 & Szwecja & 1,15 & 1,55 \\
\hline 13 & W. Brytania & 1,79 & 1,21 & 27 & Austria & 1,06 & 1,45 \\
\hline 14 & Czechy & 1,78 & 2,07 & 28 & Włochy & 0,91 & 1,39 \\
\hline
\end{tabular}

Źródło: [Wilkowicz 2018, s. A8].

W związku z niskimi stopami procentowymi banki europejskie zarabiają coraz mniej na pożyczaniu środków pieniężnych. W ten sposób zmniejszają się zyski banków, ale nie w Polsce. W Polsce systematycznie podnoszone są opłaty pozaodsetkowe. Analiza sytuacji kredytowej za lata 2016 i 2017 wykazała systematyczny wzrost pozaodsetkowych kosztów kredytowania przedsiębiorstw. Z przeprowadzonych ankiet wynika, że banki planują zaostrzenie kryteriów polityki kredytowej [Sytuacja na rynku kredytowym... 2017; 2018, s. 3-6]. Do zaostrzenia przyczyniła się ocena przewidywanej sytuacji gospodarczej oraz wzrost ryzyka związanego z kredytowaniem podmiotów w niektórych branżach. Dodatkowo wystąpił spadek popytu zgłoszonego przez duże przedsiębiorstwa, spowodowany mniejszym zapotrzebo- 
waniem na finansowanie inwestycji oraz na finansowanie zapasów i uzupełnienie kapitału obrotowego. Wyniki ankiety przeprowadzonej w II kwartale 2017 r. wykazały dodatkowo, że banki skróciły maksymalny okres kredytowania i podwyższyły pozaodsetkowe koszty kredytu. Należą do nich różnego rodzaju opłaty i prowizje określone w regulaminach kredytowania [Sierpińska, Jachna 2007, s. 271], m.in.:

- prowizja przygotowawcza (up-front fee) - stanowi zapłatę na rzecz banku za czynności związane z przygotowaniem umowy; jest to procent od całej kwoty kontraktu, a data płatności jest związana $\mathrm{z}$ datą podpisania umowy; czasem prowizja jest ustalana kwotowo;

- prowizja od uruchomienia (star-up fee) - obliczana od kwoty (transzy) uruchamianego kredytu i pobierana w momencie wypłaty;

- prowizja za organizację (arrangement fee) - występuje najczęściej, gdy kredytu udziela lub współpracuje przy emisji więcej niż jeden bank. Pobiera ją bank, który organizuje finansowanie (poszukuje środków, jest odpowiedzialny za sporządzenie umowy itp.);

- opłata agencyjna (agency fee) - jest zapłatą za obsługę i organizację emisji lub kredytu w poszczególnych odstępach czasu, najczęściej rocznie (dotyczy całego okresu kredytowania);

- prowizja za gotowość do uruchomienia (commitment fee) - stanowi procent od niewykorzystanej części kredytu i jest zapłatą za gotowość uruchomienia środków;

- prowizja za wcześniejszą spłatę - jest „karą” dla przedsiębiorstwa za zwrot środków przed terminem zawartym w umowie; dla banku stanowi refundację lub rekompensatę utraconych korzyści;

- zwrot innych wydatków poniesionych przez bank w związku z kredytem lub emisją, np. opłaty pocztowe, telekomunikacyjne, doradztwo prawne, audyt, refundacja opłat na rzecz Bankowego Funduszu Gwarancyjnego.

Zwykle możliwość uzyskania kredytu lub pożyczki uwarunkowana jest koniecznością dokonania jej zabezpieczenia. Ma ono na celu zagwarantowanie wierzycielowi zwrotu kapitału. Jest również stosowane przy emisji papierów komercyjnych dla zabezpieczenia ich powodzenia. Do najczęściej stosowanych zabezpieczeń kredytów generujących dodatkowe koszty ich wycen i rejestracji należą: hipoteki, zastawy rejestrowe, poręczenie spłaty (wekslowe lub według prawa cywilnego), przelew wierzytelności lub cesja praw do rachunku dłużnika, gwarancja bankowa, hipoteka na majątku. Z punktu widzenia minimalizacji kosztów najkorzystniej jest nie zabezpieczać kredytu lub emisji. Często jednak zabezpieczenie jest warunkiem uzyskania dostępu do kapitału, dlatego konieczna jest dokładna analiza (koszty, możliwości zamiany, przedłużenia itp.) oraz wybór optymalnej formy zabezpieczenia. 


\section{Finansowe koszty pozyskania innych źródel finansowania}

Korzystając z rynku długu, podmioty gospodarcze mogą pozyskać kapitał poprzez emisje obligacji. Przeprowadzenie programu emisji wiąże się z poniesieniem kosztów: zarówno zmiennych, wynikających z wielkości emisji i oprocentowania na rynku, jak i stałych. Należą do nich:

- oprocentowanie uzależnione od wysokości rynkowych stóp procentowych, bieżącej płynności rynku, wielkości emisji - transz, pozycji emitenta (sytuacja finansowa, pozycja rynkowa itp.) i rodzaju zabezpieczenia emisji;

- prowizja za plasowanie emisji;

- koszty stałe związane z programem emisji, takie jak prowizja banku za przygotowanie i organizację emisji, koszt sporządzenia memorandum informacyjnego dla inwestorów, inne prowizje, np. dla agencji ratingowej, prowizja za przyrzeczenie objęcia części lub całości emisji w przypadku trudności z uplasowaniem na rynku (underwritting), oraz inne koszty, związane z obsługą prawną emisji, prowadzeniem rejestru nabywców, organizacją przetargów oraz rozliczeniami finansowymi między emitentem a inwestorem.

Podstawowym kosztem emisji obligacji są odsetki płacone inwestorom. Oprocentowanie obligacji na rynku polskim jest na ogół ustalane na podstawie stawki WIBOR 3M lub 6M, natomiast obligacje denominowane w euro z kuponem odsetkowym płatnym co kwartał mogą mieć stopę bazową opartą na EURIBOR 3M, do której dodawana jest marża. W Polsce najczęściej emitowane są obligacje o zmiennej stopie procentowej, z marżą od 3,30\% do 6,5\% powyżej WIBOR. Na rynku Catalyst średnia marża wynosi od 4 do 7\% powyżej WIBOR [Sierpińska-Sawicz, Bąk 2016, s. 110].

Oprócz płatności odsetek dla inwestorów emitent ponosi koszty zorganizowania emisji. Przygotowaniem emisji zajmują się domy maklerskie, banki inwestycyjne bądź instytucje finansowe. Pobierają one opłatę, zwaną success fee, za uplasowanie emisji. Przy dużych ofertach na rynku Catalyst waha się ona od 1,5 do 2,0\% wartości emisji, natomiast przy małych wynosi ok. 4-5\% [Sierpińska-Sawicz, Bąk 2016, s. 111]. Na koszty pozyskania środków z emisji obligacji wpływa też rodzaj oferty. Oferta prywatna pociąga za sobą niższe koszty niż publiczna. Sprowadzają się one do przygotowania dokumentacji oraz sprzedaży emisji. Emisja publiczna wymaga większych wydatków, m.in. na doradztwo prawne i finansowe oraz reklamę. Emitent ma ponadto określone w przepisach obowiązki informacyjne wobec obligatariuszy i organów nadzoru, takie jak publikowanie raportów bieżących i okresowych, które generują bieżące koszty obsługi emisji. Analizując koszty emisji obligacji, trzeba również uwzględnić koszty ewidencji obligacji. W przypadku wprowadzenia papierów do obrotu na Catalyst dodatkowo trzeba wnieść opłaty na rzecz organizatora obrotu.

Obecnie finansowanie rozwoju przedsiębiorstw w Polsce odbywa się w dużym stopniu poprzez leasing finansowy bądź operacyjny. Coraz częściej korzystają z 
leasingu firmy niemające zdolności kredytowej z powodu braku zabezpieczeń. W przypadku negatywnej oceny rynkowej zdolności kredytowej przez organy podatkowe koszty korzystania z leasingu nie pomniejszą w całości podstawy opodatkowania. Podstawowym kosztem korzystania $\mathrm{z}$ leasingu są raty leasingowe, stanowiące wynagrodzenie płacone leasingodawcy za oddany do korzystania przedmiot [Wysocka 2008, s. 71]. Korzystający z leasingu, podobnie jak kredytobiorcy, muszą wykazać się zdolnością do spłaty zobowiązania. Jednakże klientami firm leasingowych mogą być firmy o słabszej kondycji finansowej, niż przewidują wymagania banków. Transakcje leasingowe zabezpieczone są podobnie jak kredyty (weksle, poręczenia, fundusz gwarancyjny).

Koszty leasingu uwarunkowane są rodzajem zawartej umowy. W przypadku leasingu operacyjnego cała opłata leasingowa ujęta jest w kosztach przedsiębiorstwa. Umowa leasingu finansowego ma bardziej rygorystyczny charakter. Podstawę opodatkowania pomniejsza amortyzacja i czynsz leasingowy, a rata kapitałowa nie ma wpływu na dochód do opodatkowania. Dodatkowo, jeśli korzystający zerwie umowę przed upływem okresu, na jaki została zawarta, może się liczyć z koniecznością zapłacenia pozostałej sumy czynszów leasingowych, obejmujących również kwoty odsetek. Zgodnie z nowymi rozwiązaniami podatkowymi będą one pomniejszać podstawę opodatkowania do wysokości limitu kosztów finansowania dłużnego. W literaturze podkreśla się, że korzystanie z leasingu jest droższe w stosunku do kredytu, jednak warunkiem właściwej oceny powinna być szczegółowa kalkulacja opłacalności obu transakcji, uwzględniająca konkretne przypadki [Burżacka-Majcher, Grzywacz 2007, s. 75].

Od 2018 r. przy doborze źródeł finansowania firmy będą musiały uwzględnić limit kosztów, które mogą ująć w kosztach uzyskania przychodów. Wpłynie to niewątpliwie na kształtowanie optymalnej struktury kapitału przedsiębiorstw. Będą one szerzej sięgać po elastyczne krótkoterminowe źródła finansowania, takie jak faktoring, forfaiting, kredyty krótkoterminowe, zobowiązania wekslowe czy kredyt kupiecki. Źródła długoterminowe są bowiem droższe niż krótkoterminowe ze względu na ciągłość korzystania, wyższe premie za ryzyko, ostrzejsze i kosztowne zabezpieczenia. Przykładowo, korzystanie z hipoteki jako zabezpieczenia kredytu czy transakcji leasingowej narzuca konieczność rynkowej wyceny majątku zastawczego i jej rejestracji, co generuje dodatkowe koszty. Wykorzystanie źródeł krótkoterminowych do finansowania rozwoju może negatywnie wpłynąć na poziom płynności finansowej podmiotów gospodarczych.

\section{Zakończenie}

Reasumując, trzeba podkreślić, że każdy rodzaj kapitału charakteryzuje się innym poziomem kosztu. Stąd różnice w koszcie pozyskania poszczególnych rodzajów kapitału dają firmom możliwość kształtowania optymalnej struktury długu, przy której koszty jego pozyskania będą najniższe. Racjonalny dobór źródeł finansowania 
staje się obecnie ważny z punktu widzenia limitu kosztów finansowania dłużnego pomniejszających podstawę opodatkowania, wprowadzonego w 2018 r. Nowe rozwiązania rozliczania kosztów finansowania dłużnego w ciężar kosztów podatkowych mogą przysporzyć niektórym firmom sporo problemów. Przy ocenie rynkowej zdolności kredytowej nieuwzględniane się bowiem w odpowiednim stopniu powiązania w grupach kapitałowych, które zwiększają zdolność kredytową podmiotów grupy poprzez wzajemne gwarancje i zabezpieczenia. Nadmierne korzystanie $\mathrm{z}$ długu w porównaniu z rynkową zdolnością kredytową, oszacowywaną w sposób uznaniowy przez organy podatkowe, może spowodować brak możliwości odliczenia kosztów jego pozyskania od podstawy opodatkowania. Zwiększy to koszty kapitału i może obniżyć tempo rozwoju firm. Tymczasem firmy w krajach Unii Europejskiej mają niższe koszty korzystania z kapitałów obcych i mogą się szybciej rozwijać. Rozwiązania podatkowe mogą zatem zaburzać konkurencyjność na rynku wspólnotowym.

\section{Literatura}

Burżacka-Majcher M., Grzywacz J., 2007, Leasing w przedsiębiorstwie, Wydawnictwo SGH, Warszawa.

Dyrektywa Rady (UE) 2016/1164 z 12 lipca 2016 r. ustanawiająca przepisy mające na celu przeciwdziałanie praktykom unikania opodatkowania, które mają bezpośredni wpływ na funkcjonowanie rynku wewnętrznego, https://publications.europa.eu/pl/publication-detail/-/publication/029ea67e-4d76-11e6-89bd-01aa75ed71a1/language-pl (10.03.2018).

https://www.bankier.pl/kredyty-hipoteczne/stopyprocentowe/wibor/libor/euribor (6.03.2018).

Klepacki J., 2016, Ryzyko polityki ujemnych stóp procentowych, Zeszyty Naukowe Uniwersytetu Szczecińskiego, Finanse, Rynki finansowe, Ubezpieczenia, nr 4 (982), cz. 1, s. 721-728.

Leszczyłowska A., 2017, Limitowanie odliczania odsetek jako kosztów w podatku dochodowym w Republice Federalnej Niemiec - istota i skutki, Prace Naukowe Uniwersytetu Ekonomicznego we Wrocławiu, Reserch Papers of Wrocław University of Economics, nr 488, s. 76-87.

Niedostateczna kapitalizacja - fundamentalne zmiany w CIT od 2018 roku, http://ksiegowosc.infor. $\mathrm{pl} /$ podatki/cit/cit/koszty/767685,Niedostateczna-kapitalizacja-fundamentalne-zmiany-w-CIT-od2018-roku.html (16.01.2018).

Sierpińska M., Jachna T., 2007, Metody podejmowania decyzji finansowych, Wydawnictwo Naukowe PWN, Warszawa.

Sierpińska-Sawicz A., Bąk P., 2016, Costs of corporate bond issue in coal mining companies, Contemporary Economics, vol. 10, issue 2, s. 99-112.

Sytuacja na rynku kredytowym - wyniki ankiety do przewodniczacych komitetów kredytowych IV kwartat 2017 r., 2017, Departament Stabilności Finansowej, Warszawa, październik.

Sytuacja na rynku kredytowym - wyniki ankiety do przewodniczących komitetów kredytowych, 2018, I kwartał, Departament Stabilności Finansowej, Warszawa, styczeń, http://www.nbp.pl/systemfinansowy/rynek_kredytowy_2018_1.pdf(10.03.2018).

Ustawa z 27 października 2017 r. o zmianie ustawy o podatku dochodowym od osób fizycznych, ustawy o podatku dochodowym od osób prawnych oraz ustawy o zryczałtowanym podatku dochodowym od niektórych przychodów osiąganych przez osoby fizyczne, Dz.U. 2017, poz. 2175. 
Wilkowicz Ł., 2018, Kredyty się sprzedaja więc nie musza być tanie, Dziennik Gazeta Prawna, 24.01. 2018, nr 17.

Wysocka M., 2008, Kredyt czy leasing? Analiza porównawcza, Wydawnictwo A.D. Drągowski, Warszawa. 